\title{
Systolic blood pressure of dogs at hospital and domestic environment
}

\author{
Pressão arterial sistólica de cães nos ambientes hospitalar e doméstico
}

\author{
Frederico Aécio Carvalho Soares ${ }^{*}$ Elisa Barp Neuwald ${ }^{I I}$ Verônica Santos Mombach ${ }^{\mathrm{I}}$ \\ Ana Elize Ribeiro D’AvilaIII Francisco de Oliveira Conrado ${ }^{\text {III }}$ Félix Hilario Diaz González ${ }^{\text {IV }}$
}

\section{ABSTRACT}

The measurement of blood pressure (BP) is an important assessment of the cardiovascular system, being influenced by physical and pathological conditions. Certain situations of stress and anxiety during BP measurement can lead to elevated values in small animals, known in medicine as "white coat effect". The aim of this research was to compare systolic blood pressure (SBP) measurement using Doppler ultrasonography in 45 adult healthy dogs in two environments, at a veterinary hospital and at home. Comparison of heart rate, serum concentrations of cortisol and glucose intended to help the evaluation of the stress level of the animals. The mean of SBP at the veterinary hospital was $154.7 \mathrm{mmHg}$ and it was significantly $(P<0.01)$ higher than at home $(136.3 \mathrm{mmHg})$. It was also observed that HR (mean $=122.7 \mathrm{bpm})$, and serum

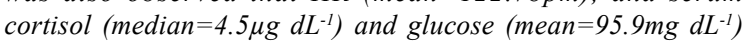
concentrations were significantly higher $(P<0.01)$ at the hospital, when compared with values obtained at home

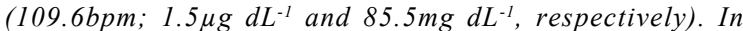
conclusion, the environment can influence SBP in dogs, due to factors related to stress.

Key words: systemic hypertension, Doppler ultrasonography, serum cortisol concentration, white coat effect.

\section{RESUMO}

A medida da pressão arterial constitui uma importante avaliação do sistema cardiovascular, sendo influenciada por condições físicas e patológicas. Situações de estresse e ansiedade no momento da aferição podem causar valores de pressão sanguínea elevados, o que é conhecido na medicina humana como "efeito jaleco branco". O objetivo deste trabalho foi comparar os valores da pressão arterial sistólica (PAS) pelo método Doppler em 45 cães em dois ambientes, o doméstico e o hospitalar. Além disso, foram comparadas as frequências cardiacas e concentrações séricas de glicose e cortisol nos dois ambientes, com o objetivo de auxiliar a avaliação o nível de estresse dos animais. A média de PAS observada no hospital foi de $154,7 \mathrm{mmHg}$ e foi significativamente superior que a observada em casa (136,3mm $\mathrm{mg}$ ). Também foi observado que os valores de FC (média $=122,7 \mathrm{bpm}$ ) e concentrações séricas de cortisol (mediana $=4,5 \mu \mathrm{g} d L^{-1}$ ) e glicose (média=95,9mg $d L^{-1}$ ) foram superiores $(P<0,01)$ no ambiente hospitalar, quando comparados com os valores obtidos no lar dos animais (109,6bpm; 1,5 $\mu \mathrm{g} d L^{-1}$ e 85,5mg $d L^{-1}$, respectivamente). Assim, condições ambientais podem influenciar a PAS em cães, devido a fatores relacionados ao estresse.

Palavras-chave: hipertensão arterial sistêmica, ultrassonografia Doppler, cortisolemia, efeito jaleco branco.

\section{INTRODUCTION}

In the past years, blood pressure (BP) measurement became a useful tool to diagnose and evaluate several diseases in dogs (BROWN et al., 2007). It is an important assessment of the cardiovascular system, being influenced by physical and pathological conditions (BROWN et al., 2007). Certain situations of stress and anxiety during BP measurement can lead to

'Hospital de Clínicas Veterinárias, Universidade Federal do Rio Grande do Sul (UFRGS), Av. Bento Gonçalves, 9090, 91540-000, Porto Alegre, RS, Brasil. E-mail: fredaecio@gmail.com.*Autor para correspondência.

IIPrograma de Pós-graduação em Ciências Veterinárias (PPGCV), UFRGS, Porto Alegre, RS, Brasil.

II'Laboratório de Análises Clínicas Veterinárias (LACVet), UFRGS, Porto Alegre, RS, Brasil.

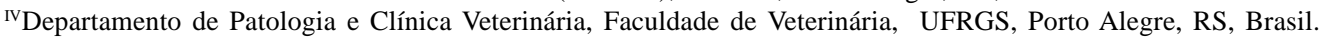


elevated values in small animals. The increase of BP in the hospital environment, known as white coat hypertension, is well described in humans and has already been studied in dogs (REMILLARD et al., 1991; VINCENT et al., 1993; KALLET et al., 1997; BODEY \& MICHELL, 1997; MOESGAARD et al., 2007) and cats (BELEW et al., 1999). Although the physiologic cause of the white coat hypertension is not precisely known, it is thought to be an alerting or defense reaction involving the sympathetic nervous system in response to the stress associated with the clinical setting (MISHINA et al., 1999). This effect can lead to a false diagnosis of hypertension and its subsequent unnecessary treatment (BELEW et al., 1999).

Doppler ultrasonography is a technique for indirect BP measurement well applicable to a clinical setting (TILLEY \& HENIK, 2002; BROWN et al., 2007). This method is more accurate to measure the systolic than diastolic pressure (BROWN et al., 2007; CABRAL et al., 2010), and it was demonstrated that systolic pressure is more important to assess tissue damage related to hypertension (MANCIA et al., 2001; MENTARI \& RAHMAN, 2004).

The aim of this research was to compare systolic blood pressure (SBP) measurement in adult healthy dogs in two environments, at the veterinary hospital and at home. Besides that, comparison of SBP, heart rate (HR), serum concentrations of cortisol and blood glucose aimed to help the evaluation of animals stress level.

\section{MATERIAL AND METHODS}

This study was performed at a Veterinary

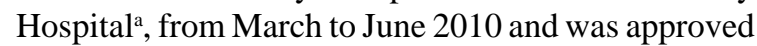
by the ethics committee. Fifty-two dogs with normal body condition score participated in this research. Only 45 dogs were considered healthy on the basis of clinical history, physical examination and complementary tests. The complementary tests were electrocardiogram (ECG), complete blood count (CBC), liver and renal evaluation (serum ALT activity and creatinine concentration), and SBP measurement. Serum concentrations of cortisol and glucose were measured in order to additionally assess the stress level of animals. Seven dogs were excluded of the study because of systemic hypertension (2), leucocytosis (1), increased ALT activity (1), presence of a murmur on cardiac auscultation (1) or arrhythmias on the ECG (2).

Among the animals studied, most were mongrel (24); breeds included Boston Terrier (3), Boxer (3), Poodle (3), Labrador Retriever (2) Yorkshire (2), French Bulldog, Golden Retriever, Lhasa Apso, German
Shepherd, Pinscher, Pit Bull Terrier, Schnauzer, and Scottish Terrier (one each). The ages ranged from one to ten years, with a mean of 4.8 years. Animal weights ranged from 2.1 to $42.2 \mathrm{~kg}$, with a mean of $16.5 \mathrm{~kg}$. There were 30 females (67\%) and 15 males (33\%).

The SBP was measured twice, once at the animal's home and again at the University Veterinary Hospital. A group of 22 animals had the first SBP measurement at home, while 23 dogs had the first SBP measurement at the hospital. The interval between the two examinations ranged between 5 and 12 days and the measurement of SBP was performed by two trained clinicians, using a vascular Doppler ultrasonography device $^{\mathrm{b}}$. To reduce and eliminate the variables associated with personnel, individuals involved in this research were the same throughout the experiment and made efforts to behave in an identical manner in both environments. Dog owners were present at all times.

The determination of SBP was standardized, after a ten minute period of acclimation to the veterinary hospital environment or to the presence of examiners at home. Doppler ultrasound SBP measurement was performed using previously described techniques (BROWN et al., 2007). The animal was positioned in right lateral recumbency and hair was removed from the region between the carpal and metacarpal pads, where coupling gel and the ultrasound probe were applied. The cuffed arm was positioned at the heart level during measurements. Also, the limb circumference was measured to choose the appropriate cuff to be used, standardizing a cuff width of $40 \%$ of the circumference of the limb (BROWN et al., 2007). The cuff was inflated to no less than $40 \mathrm{mmHg}$ above the audible cutoff point of the signal. The pressure recorded was the pressure at which the audible pulse signal was again detected. Six values of SBP were recorded and the first value was discarded. The mean value of the other five measurements was considered for statistical evaluation.

In order to avoid circadian variations of the evaluated parameters in the study, examinations of each animal were standardized, being carried out in similar time at both environments, ranging up to two hours before or after the time of the first measure. In addition, all SBP measurements were made between 9:00 and 16:00 hours, avoiding the two pressure peaks described in dogs, which correspond to 8:00 and 19:00 hours (MISHINA et al., 1999).

At the hospital, after the SBP measurement, an ECG was performed, and blood collected for determination of CBC, ALT, creatinine, glucose and cortisol. The ECG ${ }^{\mathrm{c}}$ was carried out in six leads for one minute with the patient positioned in right lateral 
recumbency. Blood samples were collected from the jugular, cephalic and/or lateral saphenous veins into tubes with EDTA K2 15\% ${ }^{\mathrm{d}}$ for blood count, and in nonadditive tubes ${ }^{e}$ to determine ALT activity and creatinine, glucose and cortisol concentrations. Blood counts were performed with an automatic cell counter ${ }^{\mathrm{f}}$ and biochemical tests were performed by spectrophotometry ${ }^{\mathrm{g}}$. Serum concentration of cortisol was performed by chemiluminescence ${ }^{\mathrm{h}}$.

At home, SBP was measured and after blood samples were collected to determine serum cortisol and glucose concentrations. Moreover, dogs were auscultated to evaluate HR for comparison with data from the ECG. The SBP measurement was always the first procedure performed at both environments.

Statistical analyses were performed in a computerized statistical software ${ }^{i}$. Values of SBP, HR and glucose concentrations showed a normal distribution, so paired t-tests were used to compare these data of both environments. To evaluate cortisol concentrations, Wilcoxon test was used. The variation of SBP in both environments was calculated and Mann Whitney test was used to evaluate the possible influence of the order of local of measurement. Values of $\mathrm{P}<0.01$ were considered significant.

\section{RESULTS AND DISCUSSION}

The values of SBP, HR and serum cortisol and glucose concentrations were significantly higher $(\mathrm{P}<0.01)$ at the hospital, when compared with values obtained at homes (Table 1). There was no influence of location of the first assessment over the SBP values observed at both environments $(\mathrm{P}=0.72)$. In the present study, the mean values of SBP found at the two environments can be considered similar when compared to other studies performed in healthy dogs, using noninvasive methods (REMILLARD et al., 1991; BODEY \& MICHELL, 1996; STEPIEN et al., 2003; CABRAL et al., 2010).

Table 1 - Mean \pm standard deviation of systolic blood pressure (SBP), heart rate (HR) and serum glucose concentration and median (\%25-\%75) of serum cortisol concentration of 45 healthy dogs at two environments, their homes and a Veterinary Hospital.

\begin{tabular}{lll}
\hline Physiological index & \multicolumn{1}{c}{ Home } & Veterinary Hospital \\
\hline SBP $(\mathrm{mmHg})$ & $136.3 \pm 21.2$ & $154.7 \pm 24.9^{*}$ \\
HR (beats $\left.\mathrm{min}^{-1}\right)$ & $109.6 \pm 25.2$ & $122.7 \pm 26.2^{*}$ \\
Cortisol $\left(\mu \mathrm{dL}^{-1}\right)$ & $1.5(1.08-3.33)$ & $4.5(2.73-5.90)^{*}$ \\
Glucose $\left(\mathrm{mg} \mathrm{dL}^{-1}\right)$ & $85.5 \pm 15.5$ & $95.9 \pm 13.3^{*}$ \\
\hline
\end{tabular}

*Significantly $(\mathrm{P}<0.01)$ different.
The results show that a white coat effect occurs in dogs at the veterinary hospital, reducing the reliability of SBP measurements at such place. Moreover, the increase in HR and in serum cortisol and glucose concentrations observed at the hospital, in comparison with those observed at home, demonstrated the presence of stressful factors. According to a study with cats, there are two different moments associated with increased HR and BP in the clinic setting, transportation and physical exam (BELEW et al., 1999). Besides these, the identity and behavior of the personnel involved are likely to contribute to the white coat effect (BELEW et al., 1999; HSIANG et al., 2008). Other factors may contribute to SBP elevation in the veterinary hospital, such as the physical presence or pheromones of other animals, which should be evaluated in further researches.

Some studies evaluated BP and HR in dogs at different environments. In a study using the oscillometric method, SBP, diastolic BP and HR obtained from the metatarsal and metacarpal sites of dogs at home were significantly lower than the measurements from the metatarsal site at the veterinary clinic, but were similar to those obtained from the metacarpal area (KALLET et al., 1997). Using similar methods, another study also found an increase of BP, but not in HR measurements obtained in a clinic versus a neutral environment (VINCENT et al., 1993). Using Doppler ultrasonography techniques, a study reported that HR, but not BP, was significantly higher when dogs were at the clinic than when they were at home (REMILLARD et al., 1991). However, these studies assessed a smaller number of dogs, which may explain the fact that the variation does not occurred for all parameters. In addition, there may be variation in approach and standardization of evaluation methods, which may have occurred from one study to another.

Clinical signs of hypertension in human beings, such as headaches, weakness and anxiety, are not readily recognizable in dogs, whereas a BP measurement may reveal a subclinical disease (REMILLARD et al., 1991; SANAN \& ARSLAN, 2007). Among the dogs excluded from the study due to changes in the physical examinations and complementary tests, two were discarded due to hypertension (SBP above $250 \mathrm{mmHg}$ at both environments). These animals, however, did not show any clinical signs, demonstrating the importance of BP measurement in routine veterinary medicine, allowing an early diagnosis prior to clinical manifestation (MISHINA et al., 1999).

Different values have been proposed to diagnose systemic hypertension in canine patients, 
however systemic hypertension is problematic mainly because chronically sustained increases in BP cause injury to tissues (REMILLARD et al., 1991; BROWN et al., 2007). In dogs, constant values of SBP between 160 and $179 \mathrm{mmHg}$, and above $180 \mathrm{mmHg}$ represent, respectively, moderate and severe risk to organ damage (BROWN et al., 2007). In the present study, five animals (11\%) had SBP between 160 and $179 \mathrm{mmHg}$ at home, and two (4\%) had SBP above 180mmHg. Meanwhile, at the hospital environment, eight animals (18\%) had SBP between 160 and $179 \mathrm{mmHg}$, and six (13\%) had SBP above $180 \mathrm{mmHg}$. In humans, target-organ damage from hypertension appears to be better correlated with the ambulatory, measured throughout the day, than the isolated office value of BP(GOOSE et al., 1993; GELEILETE et al., 2009), and probably, in dogs, the home SBP may be used to evaluate this damage, since it may reflect more accurately the value of SBP in resting animals.

Two dogs in this research had a mean SBP value of $218 \mathrm{mmHg}$ at the hospital, but the physical examination and complementary tests were normal. In the following week, these animals were subjected to the second BP measurement, this time at home. The average value of SBP was lower than $160 \mathrm{mmHg}$, which corroborates with the idea that there is a white coat effect in dogs. Besides that, this observation points out the danger of diagnosing hypertension in dogs based on a single BP measurement in unfamiliar surroundings. This fact was also observed in cats and humans, and the magnitude of increase in SBP varies considerably among individuals and among visits in the same individual (GOOSE et al., 1993; KALLET et al., 1997; BELEW et al., 1999). Unfortunately, the effects of anxiety on BP are not predictable, and some animals may exhibit a dramatic increase in BP whereas others do not (BROWN et al., 2007).

The white coat hypertension was already documented in dogs (REMILLARD et al., 1991; VINCENT et al., 1993; KALLET et al., 1997; BODEY \& MICHELL, 1997; MOESGAARD et al., 2007); however, the relation of increases in BP in canine patients at a hospital environment with the development of systemic diseases is unknown. In cats, higher values of SBP occur with induced renal insufficiency than in healthy animals during simulated office visits (BELEW et al., 1999). It is apparent that differences in the magnitude of the white coat effect may be observed in animals with certain diseases and this could interfere with the accuracy of measurements of BP in these animals. Moreover, further studies must be performed in dogs to evaluate if the white coat is a benign event or may predict the development of other diseases, such as renal or cardiovascular alterations.
Serum cortisol and glucose levels were significantly higher at the hospital environment, but the median/mean values were within reference values for dogs, from 0.5 to $5.5 \mu \mathrm{g} \mathrm{dL}^{-1}$, and 65 to $118 \mathrm{mg} \mathrm{dL}^{-1}$, respectively (MEIJ \& MOL, 2008). In dogs, a change of sympathetic tone caused by the presence of foreign people and/or environment is mainly responsible for the fast increase of BP under clinical conditions (VINCENT et al., 1993). Almost any type of stress, whether physical or psychogenic, causes an immediate and marked increase in the secretion of ACTH by the anterior pituitary, followed within minutes by greatly increased adrenocortical secretion of cortisol (GUYTON \& HALL, 2000). In dogs and cats with various types of stress, elevations in blood glucose are observed, due to the effects of epinephrine and cortisol (ALLEN, 1987). An environment such as the veterinary hospital, with the presence of other animals and strangers, in addition to physical restraint for examination, may be considered stressful to the animal. In dogs, a study observed that several plasma markers were affected by the white coat effect; however, cortisol concentration was not evaluated (MOESGAARD et al., 2007). It was also demonstrated that cortisol in the saliva increases within minutes after specific acoustic stimuli (BEERDA et al., 1998; HYDBRING-SANDBERG et al., 2004), and cortisol in serum increases after fear simulations (HYDBRINGSANDBERG et al., 2004) or environmental challenges in dogs (HAVERBEKE et al., 2008). A stress-induced increase in cortisol levels would not be expected until 30 minutes after the stressful incident (VINCENT \& MICHELL, 1992). In the present study, the blood collection was the last procedure, performed about 30 minutes after the first contact with the animals, and it was demonstrated that the white coat effect is associated with increases in cortisol secretion.

To identify stress in animals, it is important not to depend on a single criterion, such as changes in cortisol secretion, but preferably to use at least one endocrine and one cardiovascular indicator, alongside behavioral observations. Among the cardiovascular indicators, those most often used are HR and BP (VINCENT et al., 1993). In this research, both endocrine (cortisol and glucose serum concentrations) and cardiovascular (SBP and HR) indicators were assessed and demonstrated that the visit to a veterinary hospital is a stressful situation for dogs. Also, the canine population is very heterogeneous, and BP values may be influenced by age, sex, breed, size, body condition, exercise regimen of the animals, and by the method of measurement (VINCENT et al., 1993; BODEY \& MICHELL, 1996; BODEY \& MICHELL, 1997; MICHELL, 2000; MONTOYA et al., 2006; BROWN et 
al., 2007; CABRAL et al., 2010). Further studies are necessary to establish if the white coat hypertension differs into these groups.

\section{CONCLUSION}

The environment can influence SBP in dogs, due to factors related to stress. It is therefore important that the procedure can be standardized, performed with the animal calm and quiet, after an acclimation period. Also, a first measurement is not sufficient to diagnose hypertension, requiring at least one re-examination, if possible in an environment where the animal is adapted, as its home.

\section{SOURCESAND MANUFACTURES}

a - Veterinary Clinical Hospital of Federal University of Rio Grande do Sul, Porto Alegre, Brazil.

b - Vascular Doppler Medmega (model DV610), São Paulo, Brazil.

c - ECG-TEB, version C10, Tecnologia Eletrônica Brasileira, São Paulo, Brazil.

d - BD Vacutainer ${ }^{\circledR}$, 367856, São Paulo, Brazil.

e - BD Vacutainer ${ }^{\circledR}$, 367812, São Paulo, Brazil.

f - ABX Micros ABC Vet, Horiba Medical, São Paulo, Brazil.

g - Metrolab 1600 DR, UV-Vis Metrolab S.A., Buenos Aires, Argentina.

h - Unicell-DxI 800, Beckman Coulter Inc., California, USA. i - SPSS (Statistical Package for the Social Science) version 19.0, SPSS Inc., Chicago, USA.

\section{BIOETHICS AND BIOSSECURITY COMMITTEE APPROVAL}

The present study was approved by Ethics Committee on Use of Animals, Federal University of Rio Grande do Sul, under process number 18391.

\section{REFERENCES}

ALLEN, T.A. The endocrine pancreas. In: DRAZNER, F.H. Small animal endocrinology. New York: Churchill Livingstone, 1987. Cap.6, p.161-199.

BEERDA, B. et al. Behavioural, saliva cortisol and heart rate responses to different types of stimuli in dogs. Applied Animal Behaviour Science, v.58, p.365-381, 1998. Available from: <http://www.journals.elsevierhealth.com/periodicals/applan/ article/PIIS0168159197001457/>. Accessed: Jun. 12, 2011. doi: 10.1016/S0168-1591(97)00145-7.

BELEW, A.M. et al. Evaluation of the white-coat effect in cats. Journal of Veterinary Internal Medicine, v.13, p.134142, 1999. Available from: <http://www.ncbi.nlm.nih.gov/ pubmed/10225603>. Accessed: Jun. 12, 2011. doi: 10.1111/ j.1939-1676.1999.tb01141.

BODEY, A.R.; MICHELL, A.R. Epidemiological study of blood pressure in domestic dogs. Journal of Small Animal Practice, v.37, p.116-125, 1996. Available from: <http:// www.ncbi.nlm.nih.gov/pubmed/8683954>. Accessed: Jun. 12, 2011. doi: 10.1111/j.1748-5827.1996.tb02358.

BODEY, A.R.; MICHELL, A.R. Longitudinal studies of reproducibility and variability of indirect (oscillometric) blood pressure measurements in dogs: evidence of tracking. Research in Veterinary Science, v.63, p.15-21, 1997. Available from: <http://www.ncbi.nlm.nih.gov/pubmed/9368951>. Accessed: Jun. 12, 2011. doi: 10.1016/S0034-5288(97)90152-1.

BROWN, S. et al. Guidelines for the identification, evaluation, and management of systemic hypertension in dogs and cats. Journal of Veterinary Internal Medicine, v.21, p.542-558, 2007. Available from: <http://www.cardiologiaveterinaria.com/ media/pdfs/HTA\%20Consenso.pdf $>$. Accessed: Jun. 12, 2011. doi: 10.1111/j.1939-1676.2007.tb03005.

CABRAL, R.R. et al. Valores de pressão arterial em cães pelos métodos oscilométrico e Doppler vascular. Arquivo Brasileiro de Medicina Veterinária e Zootecnia, v.62, p.64-71, 2010. Available from: <http://www.scielo.br/pdf/abmvz/v62n1/ v62n1a09.pdf>. Accessed: Jun. 12, 2011. doi: 10.1590/S010209352010000100009.

GELEILETE, T.J.M. et al. Medida ambulatorial da pressão arterial. Revista Brasileira de Hipertensão, v.16, p.242245, 2009. Available from: <http://departamentos.cardiol.br/ dha/revista/16-4/11-medida.pdf>. Accessed: Jun. 12, 2011.

GOOSE, P. et al. White coat hypertension. No harm for the heart. Hypertension, v.22, p.766-770, 1993. Available from: <http://hyper.ahajournals.org/cgi/reprint/22/5/766.pdf> Accessed: Jun. 12, 2011. doi: 10.1161/?01.HYP.22.5.766.

GUYTON, A.C.; HALL, J.E. Os hormônios adrenocorticais. In: _. Tratado de Fisiologia Médica. Rio de Janeiro, RJ: Guanabara Koogan, 2000. Cap.77, p.813-826.

HAVERBEKE, A. et al. Cortisol and behavior responses of working dogs to environmental challenges. Phisiology and Behaviour, v.93, p.59-67, 2008. Available from: <http:// w w w. sciencedirect.com/ s c i ence/a r t ic le / p i i / S0031938407002995>. Accessed: Jun. 12, 2011. doi: 10.1016/ j.physbeh.2007.07.014.

HSIANG, T.Y. et al. Indirect measurement of systemic blood pressure in conscious dogs in a clinical setting. Journal of Veterinary Medical Science, v.70, p.449-453, 2008. Available from: <http://www.ncbi.nlm.nih.gov/pubmed/ 18525165>. Accessed: Jun. 12, 2011. doi: 10.1292/ jvms.70.449.

HYDBRING-SANDBERG, E. et al. Physiological reactions to fear provocation in dogs. Journal of Endocrinology, v.180, p.439-448, 2004. Available from: <http://joe.endocrinologyjournals.org/content/180/3/439.abstract>. Accessed: Jun. 12, 2011. doi: 10.1677/joe.0.1800439.

KALLET, A.J. et al. Comparison of blood pressure measurements obtained in dogs by use of indirect oscillometry in a veterinary clinic versus at home. Journal of the American Veterinary Medical Association, v.210, p.651-654, 1997. Available from: <http://www.ncbi.nlm.nih.gov/pubmed/ 9054993>. Accessed: Jun. 12, 2011.

MANCIA, G. et al. Relation between blood pressure variability and carotid artery damage in hypertension: baseline data from 
the European Lacidipine Study on Atherosclerosis (ELSA). Journal of Hypertension, v.19, p.1981-1989, 2001. Available from: <http://www.ncbi.nlm.nih.gov/pubmed/ 11677363>. Accessed: Jun. 12, 2011. doi: 10.1097/00004872200111000-00008.

MEIJ, B.P.; MOL, J.A. Adrenocortical function. In: KANEKO, J.J. et al. Clinical biochemistry of domestic animals. San Diego, CA: Elsevier, 2008. Chap.19, p.605-622.

MENTARI, E.; RAHMAN, M. Blood pressure and progression of chronic kidney disease: Importance of systolic, diastolic, or diurnal variation. Current Hypertension Reports, v.6, p.400-404, 2004. Available from: <http:// www.ncbi.nlm.nih.gov/pubmed/15341694>. Accessed: Jun. 12, 2011. doi: 10.1007/s11906-004-0060-2.

MICHELL, A.R. Hypertension in dogs: the value of comparative medicine. Journal of the Royal Society of Medicine, v.93, p.451-452, 2000. Available from: <http://www.ncbi.nlm.nih.gov/ pubmed/11089478>. Accessed: Jun. 12, 2011.

MISHINA, M. et al. Diurnal variations of blood pressure in dogs. Journal of Veterinary Medical Science, v.61, p.643647, 1999. Available from: <http://www.ncbi.nlm.nih.gov/ pubmed/10423686>. Accessed: Jun. 12, 2011. doi: 10.1292/ jvms.61.643.

MOESGAARD S.G. et al. Effects of breed, gender, exercise and white-coat effect on markers of endothelial function in dogs. Research in Veterinary Science, v.82, p.409-415, 2007. Available from: <http://www.ncbi.nlm.nih.gov/pubmed/ 17092526>. Accessed: Jun. 12, 2011. doi: 10.1016/ j.rvsc.2006.09.003.

MONTOYA, J.A. et al. Hypertension: a risk factor associated with weight status in dogs. Journal of Nutrition, v.136, p.2011S-2013S, 2006. Available from: <http://jn.nutrition.org/ content/136/7/2011S.full>. Accessed: Jun. 12, 2011.
REMILLARD, R.L. et al. Variance of indirect blood pressure measurements and prevalence of hypertension in clinically normal dogs. American Journal of Veterinary Research, v.52, p.561-565, 1991. Available from: <http://www.ncbi.nlm.nih.gov/ pubmed/2053724>. Accessed: Jun. 12, 2011.

SANAN, T.B.; ARSLAN, M. Determination of reference arterial blood pressure values by indirect methods for Kangal dogs. Journal of Small Animal Practice, v.48, p.638-642, 2007. Available from: <http://www.ncbi.nlm.nih.gov/pubmed/ 17617159>. Accessed: Jun. 12, 2011. doi: 10.1111/j.17485827.2007 .00387 .

STEPIEN, R.L. et al. Comparative diagnostic test characteristics of oscillometric and Doppler ultrasonographic methods in the detection of systolic hypertension in dogs. Journal of Veterinary Internal Medicine, v.17, p.65-72, 2003. Available from: <http://www.ncbi.nlm.nih.gov/pubmed/ 12564729>. Accessed: Jun. 12, 2011. doi: 10.1111/j.19391676.2003.tb01325.

TILLEY, L.P.; HENIK, R.A. Hipertensão sistêmica. In: TILLEY, L.P.; GOODWIN, J.K. Manual de cardiologia para cães e gatos. São Paulo, SP: Roca, 2002. Cap.13, p.313-319.

VINCENT, I.C.; MICHELL, A.R. Comparison of cortisol concentrations in saliva and plasma of dogs. Research in Veterinary Science, v.53, p.342-345, 1992. Available from: <http://www.ncbi.nlm.nih.gov/pubmed/1334567>. Accessed: Jun. 12, 2011. doi: 10.1016/0034-5288(92)90137-Q.

VINCENT, I.C. et al. Non-invasive measurement of arterial blood pressure in dogs: a potential indicator for the identification of stress. Research in Veterinary Science, v.54, p.195201, 1993. Available from: <http://www.ncbi.nlm.nih.gov/ pubmed/8460259>. Accessed: Jun. 12, 2011. doi: 10.1016/ 0034-5288(93)90056-L. 